Tesis. Año 13, 12(14), 2019, 119-140

\title{
El estatuto semántico de la representación del Diablo en el III Concilio Limense
}

\author{
Dany Rodas-Bazán \\ dany.rodas@unmsm.edu.pe
}

\section{Resumen}

El rol de la Iglesia Católica, en el contexto de la conquista de América, ha sido descrito como una campaña que tuvo por objetivo único expandir la fe cristiana. No obstante, por medio de distintos discursos, que tienen como uno de sus ejes del concepto de Diablo, ayudaron en la consolidación de la Colonización. El siguiente artículo tiene por objetivo hallar las oposiciones semánticas presentes en los sermones del Tercer Concilio Limense, con el fin de describir el nivel temático y, a partir de allí, poder interpretar las implicancias ideológicas en torno al concepto del Diablo. Se ha utilizado como metodología la teoría expresada por Joseph Courtés en Semiótica del discurso. Luego del análisis, se concluye que la imagen del Diablo, asociada a conceptos como alma, cuerpo, pecado, perdición, entre otras sirvió para convertir al indígena peruano en un sujeto colonizado.

Palabras clave: Diablo, sermón, evangelización, análisis, colonización.

\begin{abstract}
The role of the Catholic Church, in the context of the conquest of America, has been described as a campaign whose objective was to expand the Christian faith. However, through different speeches, which have as one of its main points the concept of Devil, collaborated with the consolidation of Colonization. The next article aims to find the semantic oppositions present in the sermons of the Third Limense Council, in order to describe the temantic level and, from there, to be able to interpret the ideological implications around the concept of the Devil. The theory expressed by Joseph Courtés in Semiotics of Discourse has been used as a methodology. After the analysis, we have concluded that the image of the Devil, associated with the concepts such as soul, body, sin, perdition, among other things to turn the Peruvian indigenous into a colonized subject.
\end{abstract}

Keywords: Devil, sermon, evangelization, analysis, colonization. 


\section{EI estatuto semántico de la representación del Diablo en el III Concilio Limense}

\section{Introducción}

A la par del descubrimiento y conquista de las Indias, se llevó a cabo la misión evangelizadora. Los sacerdotes acompañaban a los soldados con el fin de ganar almas y territorios para las órdenes a las que representaban. En este contexto, los capellanes de expedición tenían un rol diplomático. Moderaban a los indígenas con sus discursos de salvación, a la vez que propiciaban condiciones menos adversas para los conquistados. A pesar de los desacuerdos con los abusos de los soldados, a los religiosos "no les repugnaba compartir el botín con los conquistadores, ni recibir indios en encomienda" (Lafaye, 1981, p. 196).

Tanto el Rey de España como el Papa tuvieron interés especial en los territorios descubiertos por Cristóbal Colón. La sociedad entre la Iglesia y la Corona se manifestó por medio de distintos documentos como la bula Inter coetera (1493), en la que Alejandro VI donó las tierras descubiertas a los Reyes Católicos. En esta bula, Alejandro VI manifiesta su deseo por expandir la fe católica reduciendo a las "barbaricae nationes". La autoridad del Papa para otorgar "in perpetuum" tierras se sustenta en la idea de que después de la presencia de Cristo en la tierra, los no cristianos habían perdido el dominio sobre sus territorios, el cual debía ser administrado por el Papa.

Para los clérigos europeos, la religión indígena era concebida como poco sofisticada en relación con el Islam o el Judaísmo, las cuales habían demostrado un grado considerable de desarrollo. Con los judíos o musulmanes se hizo debates para demostrar la falsedad de la otra fe. Hubo una confrontación de ideas en torno a "las escrituras". Nada de esto ocurrió con los indios, cuya religión resultaba - a los ojos de los europeos- salvaje, irracional e inferior: para los cristianos, los indígenas carecían de "escrituras" y de un corpus filosófico sistematizado (Gruzinski, 2016). En última instancia, los religiosos simplemente 
asumieron que las manifestaciones religiosas de los indios eran idolatrías bárbaras con las cuales era imposible entablar cualquier tipo de debate.

La Iglesia propició la redacción de textos evangelizadores en lenguas indígenas. En estos escritos, se buscó eliminar la religión anterior e instaurar la fe católica. Dado que, mediante la Pragmática del 8 de julio de 1502, los Reyes Católicos prohibieron la traducción de la Biblia al Castellano, pues esto podría generar herejías (León, 2015); se buscó dar a conocer, mediante una doctrina sencilla, los principios de la fe católica. Por medio de los sermones, el indio debía comprender su verdadera condición y lugar en el mundo: es un sujeto que comete pecados y está en riesgo de ser condenado. Para ser salvado del Infierno, debe conocer la verdadera religión, obedecer los mandatos de la Iglesia y confesar sus pecados ante el sacerdote.

Siguiendo los parámetros de la religión judeocristiana, los clérigos españoles utilizaron una oposición general para comprender el Nuevo Mundo: el bien y el mal, par que implica referentes y conceptos como Dios-Diablo, salvación-condena, cielo-infierno. Hacia 1494 fray Ramón de Pané, quien llegó en el segundo viaje de Cristóbal Colón, terminó la redacción de sus Apuntes de Relación acerca de las antigüedades de los indios. Partiendo de una posición de superioridad moral, religiosa e intelectual, Pané describe y evalúa las costumbres de los indígenas. La religión indígena se reduce a engaños, ignorancia y embustes del demonio. Más adelante, en México, Toribio de Benavente afirmaría en Tratado de los indios (1541) que los ídolos eran "figuras del demonio sucias, feas y hediondas". En la Doctrina christiana en lengua española y mexicana (1550), compuesta en sermones por los religiosos de la orden de Santo Domingo, se da a entender a los indígenas que los dioses antiguos Tezcatlipoca, Chicomecoatl, entre otros "no eran verdaderos dioses sino engañadores vellacos q hazian burla y escarnio de vosotros". La religión de los indígenas fue reducida a asuntos del demonio e ignorancia. No se buscó comprenderla. Contra ella hubo intolerancia, fanatismo y totalitarismo.

Estos textos doctrinarios, redactados en español y en distintas lenguas nativas, son antecedentes de los textos instructivos elaborados en el Tercer Concilio Limense (1582-1583), desarrollado en Lima bajo el mandato de Toribio de Mogrovejo. Producto de esta reunión se redactó un Catecismo trilingüe (castellano, quechua y aimara) hecho por José de Acosta y los mestizos Valera y Bartolomé de Santiago (Methol, 1968).

La principal hipótesis del presente estudio es que en el Sermonario del Tercer Concilio Limense, el Diablo tuvo un rol preponderante que ayudó en la colonización, pues permitió implantar en el indio los conceptos de pecado, perdición, sufrimiento, muerte y alma. En este sentido, en el presente artículo 
describiremos el estatuto semántico de la idea del Diablo en los sermones del Tercer Concilio Limense.

El texto que se ha utilizado para el análisis del estudio se titula Tercero Cathecismo y exposición de la Doctrina Christiana, por sermones para que los coras $y$ otros ministros prediquen y enseñen a los yndios y a las demas personas de 1585. Hemos recurrido a la versión presentada por Ximena Medinaceli en Estudios Bolivianos, $N^{\circ} 9$ (2001) y al texto facsímil presentado por el Concilio Provincial de Lima en la misma fecha.

En el primer apartado, Materiales y métodos, daremos a conocer de modo sucinto las herramientas teóricas utilizadas para el análisis de los textos. Seguidamente, brindaremos la descripción semántica producto del resultado del análisis. Estos consisten en un conjunto de oposiciones relacionadas con la evangelización, el concepto del Diablo y su incidencia en el indígena peruano. Por último, brindamos las conclusiones.

\section{Materiales y métodos}

Para el análisis de los sermones hemos recurrido a las categorías expuestas por Joseph Courtés en Análisis semiótico del discurso: Del enunciado a la enunciación (1997)

\section{La contrariedad semántica}

Dos conceptos son opuestos semánticamente si se encuentran relacionados en torno a una orientación sémica común. Así "sima" y "cima" son contrarios, ya que ambos se refieren a partes extremas de una montaña, cerro, entre otros. Dicho eje de relación se denomina eje sémico, el cual es una relación binaria que se establece entre dos semas a nivel profundo del contenido.

Ejemplo:

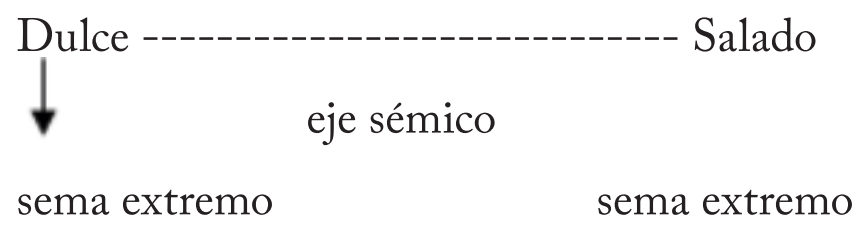

Como se aprecia en el esquema, la contrariedad se da entre dos términos extremos ligados gracias a un eje sémico. Tal contrariedad genera el binarismo, mediante el cual estructuramos nuestro pensamiento. El binarismo implica que un término extremo es opuesto del otro y viceversa, como se deduce en oposiciones como negro-blanco, mucho-poco. 
De acuerdo con Courtés (1997), el discurso posee tres niveles: a) el nivel figurativo, que refiere a todo aquello que puede ser captado por uno de los cinco sentidos. Es la manifestación del discurso más externa, lo expresado como tal; b) el nivel temático referente a los contenidos, a los significados profundos de los sistemas de representación; y c) el nivel axiológico, que remite a la valoración de los referentes o conceptos presentados en el nivel temático o axiológico. La valoración se expresa en forma de euforia (valoración positiva) o disforia (valoración negativa).

El enunciador dispone los elementos del código de tal forma que consigue que el enunciatario se adhiera a un punto de vista particular. En el texto semiótica Diccionario razonado de la teoría del lenguaje de Joseph Courtés y A. Greimas (1982), se define al enunciador como un actante implícito, presupuesto en todo enunciado: "Se llamará enunciador al destinador implícito de la enunciación". El enunciatario es el "destinatario implícito" en el discurso, del cual forma parte. La manipulación puede darse en torno a la seducción (provocar el querer-hacer), la intimidación (no-poder-hacer). El enunciador posee un poder que le permite manipular al enunciatario. Este poder consiste en la capacidad para brindar objetos positivos, como los "valores culturales" o negativos, como las amenazas. (Greimas y Courtés, 1982)

Por su parte, Fontanille (2001) define la mira como una tensión dirigida a un aspecto del mundo exterior. Es decir, implica una valoración especial por parte del enunciador. La mira aísla al objeto o sujeto de su contexto. En este sentido, lo mirado es subjetivado, comprendido en una perspectiva más personal. La mira selecciona, focaliza la tensión del enunciador; esto implica que el discurso deja de lado otros elementos que resultarán virtualizados (Fontanille, 2012).

\section{Resultados del análisis}

\section{Oposiciones semánticas en la representación del Diablo en el Tercer Concilio Limense}

Luego de hacer el análisis en los sermones del Tercer Concilio Limense (19821983) hemos encontrado las siguientes oposiciones semánticas:

En principio, hallamos la oposición arriba-abajo. Arriba se encuentran los referentes relativos a la Iglesia y la cultura europea: el conocimiento, el lenguaje, el nivel de razonamiento y la espiritualidad de los cristianos. Abajo se ubican todo lo referente a lo indígena: su escaso nivel de razonamiento, la ausencia del código escrito, el nulo conocimiento de la historia europea (cristiana), y el apego a los vicios y herejías. 
El latín se halla en un lugar privilegiado frente al español y más aún a las lenguas de los indígenas. Los religiosos entendían que las lenguas indígenas correspondían a una cultura primitiva, en la que el Diablo había influido grandemente, con lo que su acción consistió en reducir la capacidad de raciocinio e incrementar su aproximación a los sentidos. En la concepción de la Iglesia, el Diablo ha sido ligado con los placeres y los sentidos. Se aleja de lo racional y de la satisfacción de los vicios carnales.

Y Jiendo corno fon los Indios gente nueua y tierna en la doctrina del Euangelio, y lo comun dellos no de altos y leuantados entēdimiētos, ni

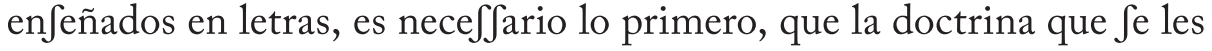

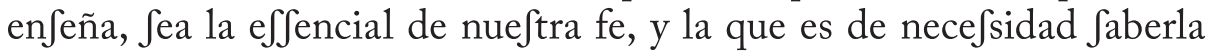
todos los chriftianos. (Tercero Cathecismo, 1585, p. 4- 5)

En segundo lugar, hallamos la oposición bien-mal. En los distintos sermones se indica que el bien es aquello que "agrada a Dios", es decir, el conjunto de cosas y acciones que impliquen un rechazo del pecado. Por su parte, el mal consiste en la desobediencia de los mandamientos, el apego a los bienes materiales o los placeres, todos ellos dominios del Diablo.

Seguidamente, hallamos la oposición hombre-animal. Los sermones ponen el énfasis en la distinción de estos dos seres, basado en la presencia del alma en el hombre, la cual ha sido puesta por Dios en el cuerpo. El alma es eterna y transita por dos vidas: la presente y la futura, ya sea en el Paraíso, el Purgatorio o el Infierno. En cambio, el animal posee una sola vida; tiene solo cuerpo y carece de razón por la falta de entendimiento que da el espíritu. En el Sermón I se brinda este conocimiento que instala en el indio un nuevo saber ontológico sobre su ser, la organización del mundo (terrenal y ultraterrenal), así como un saber axiológico sobre el bien y el mal.

La oposición cuerpo-alma es fundamental para la comprensión de la ideología religiosa, y para el control de la sociedad andina. El indígena debía saber que el alma es la que permite el habla, la vida, el movimiento, el pensamiento y los sentimientos. El alma es descrita como el nexo entre Dios y el hombre, y entre este y sus semejantes. Al llegar a la segunda vida, el alma le permitirá gozar de la presencia de Dios. Por ser el motor que brinda humanidad a la persona, el alma permite decidir entre el bien y el mal. Estas actividades cognitivas, intelectivas, afectivas y físicas, sin las cuales seríamos animales, corresponde a Dios, y el representante de Dios es la Iglesia, que llegó junto con los conquistadores. De modo que el indio se redefine su condición de sujeto: ahora posee un alma, la cual lo hace superior a los animales, los astros y los elementos (agua, aire, tierra, fuego), considerados hasta entonces como sagrados (Depaz, 2015). Asimismo, comprende que para salvar su alma debe obedecer a los religiosos y las nuevas autoridades coloniales. 
El Sermón XV incide en la administración del cuerpo, especialmente del sexo. La Iglesia aspira a controlar la familia y las acciones de la persona. E1 cuerpo es propiedad de Dios. El hombre no se pertenece a sí mismo. El sexo permitido es aquel que ha sido legitimado por el sacramento del matrimonio, que imita a la pareja básica establecida por Dios. El sexo legítimo solo tiene la función reproductiva. Otras formas de auto-control del cuerpo son sancionadas. La ruptura de estos paradigmas, como el concubinato, el adulterio, la homosexualidad, el sexo con animales y el sexo con los hombres de la Iglesia resultan aberrantes para los religiosos y para Dios. De modo que la oposición desobediencia-obediencia se liga directamente con el conocimiento y uso del cuerpo, la salvación o perdición y la pertenencia a los dominios de Dios o del Diablo.

Efte eftado de matrimonio ordeno Dios luego que crio a los primeros hombres varo y muger llamados Adam y Eua: que fuero padres de todo el linage humano. y defpues dellos en todas las gentes del mundo

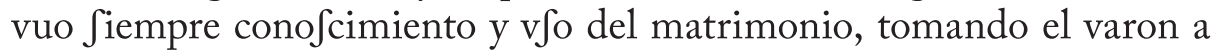
la muger por Juya, y la muger al varon por Juyo. y teniendo por cofa buena y honrofa eftar cafados hombre y muger: y al reues por cofa mala y fea eftar amancenbados, teniendo ayuntamiento como las beftias que toman unas y dexa otras, como les da el appetiro, Jin guardar ley de compañia entre $\int \mathrm{i}$. Por donde entendereys que todos los que eftan

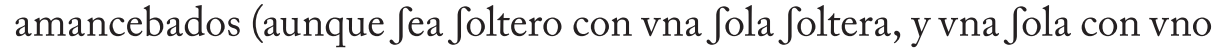
folo) eftan en peccado mortal, y fe yran a arder para Jiempre en el fuego del infierno. No os engañen los hechizeros que dizen que con vna fola

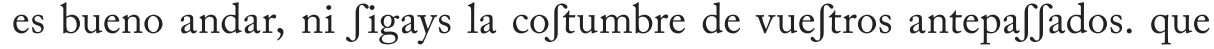
antes de cafarfe para probar la muger $\int \mathrm{e}$ amancebauan primero. $\mathrm{Y}$ a fsi lo hazeys muchos de vofotros ay dia: y en efto Joys hijos del Diablo y enemigos de la ley de Dios: la qual no da licencia de juntarfe el varan y muger carnalmente ni aun una vez Jola, antes de Jer cafados. Por efto abrid los ojos y no vfeys tal maldad de aqui adelante. (Tercero Cathecismo, 1585, p. 86)

De la administración del sexo, se deriva un control social de la pareja y de los hijos. Controlar el sexo implica el dominio de la familia. La dualidad hombre-mujer, única posible en la Creación, tiene una gran importancia para la administración social. En el Sermón XV observamos un énfasis al respecto. En el Sermón XXIV se sanciona la vida sexual desordenada. El adulterio y el amancebamiento entre no casados derivan en herejía y excomulgación. También se sancionan la pedofilia, la zoofilia, el lesbianismo, la masturbación, la sodomía y otras cosas de "grandísima abominación".

Quitad las borracheras y taquies que fon la femetera destos vicios tan abominables, apartad los muchachos y los hōbres de vueftras camas, no durmays rebueltos como cochinos, Sino cada uno por si, no digays 
cantares, ni palabras fuzias, no provoqueys a vueftra carne co vuestras manos que esto tambien es pecado y digno de muerte y infierno. (Tercero Cathecismo, 1585 , p. 1540)

Por otro lado, en el Sermón XV se expresa que el cuerpo de los incas y curacas remitían al pecado y la suciedad. La poligamia del Inca "es contra la ley de Dios”. En el Sermón XVI se brindan impedimentos para el matrimonio como no poseer el bautismo, matrimonio entre parientes, parejas adúlteras, familiares, parejas de hermanos y familiares próximos, el asesino de la pareja, entre otros casos recogidos de la Biblia (Levítico 18).

Por otro lado, la oposición Dios-hombre es representada al modo del par padre-hijo. Dios padre es mostrado como una entidad altísima, eterna, severa y justa. Como padre decide cuándo premiar o castigar al hijo, quien debe adorarlo, solicitar misericordia y la salvación del alma. Los sermones inciden más en la imagen severa que bondadosa de Dios-padre. Asimismo, se hace hincapié en el carácter creador de Dios. Con esto, se buscaba generar una idea que extremaba la diferencia entre el Altísimo y el "gusano vil", como se le llama al indio.

De acuerdo con Erich Fromm (2012), la religión genera una imagen dual del Padre, en la que resalta su carácter castigador. Este padre genera terror. Su presencia es fantasmal, angustia al cristiano (Parret, 2008). En el contexto de la Reforma, la Iglesia puso énfasis en la obediencia extrema de los fieles. En esencia, la religión busca un apego al padre creador, de modo semejante a la admiración patológica por el padre. La religión es dogmática y autoritaria. Al Ser supremo se le debe obediencia y veneración. Los religiosos obligan amar a Dios. El pecado cardinal de toda religión es la desobediencia. Al obedecer a Dios y reconocer su inferioridad, el hombre comprende que la sumisión y la pérdida de independencia e integridad son buenas: "el valor del hombre consiste en la misma negación de su valor y su fuerza” (Fromm, 1956, p. 57).

Dentro de esta oposición, el indio es concebido como un "hijo de Dios”, que recibirá justicia en el territorio celestial, donde podrá descansar de la ajetreada vida que llevaban en la Colonia. El poder de otorgar dones convierte a Dios en un destinatario. Dentro de los sermones el principal objeto de deseo que entrega Dios al hombre es la salvación.

En los sermones observamos también la dualidad Cristo-Diablo. A Cristo le corresponden los conceptos de salvación, medicina, conocimiento, pureza, bondad y sacrificio; mientras que el Diablo se relaciona con la condena, la enfermedad, la ignorancia, la corrupción, la maldad y el aprovechamiento. El Diablo y su territorio generan el terror mental necesario para conseguir el control de los cuerpos, las relaciones sociales, las ideologías, expectativas, la historia y el seguimiento de las reglas del poder. 
La oposición salvación-condena fue estratégica para la Colonización del indio. En el nivel temático, una vida pecaminosa se confronta con una vida santa en los siguientes aspectos:

\begin{tabular}{ll}
\hline \multicolumn{1}{c}{ Pecado } & \multicolumn{1}{c}{ Santidad } \\
\hline Desacato & Obediencia \\
Placer & Abstinencia \\
Tiempo pasado & Tiempo presente \\
(el reciente pasado inca) & (en que ha llegado el Evangelio) \\
Suciedad & Limpieza \\
Muerte & Vida \\
Fealdad & Belleza \\
Soledad & Compañía \\
Repugnancia & Atracción \\
\hline
\end{tabular}

La condena remite al dolor, muerte, oscuridad, suciedad, sufrimiento; todos ellos elementos correspondientes al Diablo, quien - se infiere- disfruta con el dolor de las almas, por lo que se le adjudica una personalidad psicopática, próxima al sadismo. De acuerdo con Erich Fromm (2012), un sujeto sádico somete personas para satisfacer sus pulsiones de destrucción. Aparentemente, el Diablo protege a la persona y le manifiesta cierto "amor" (en este caso, incita los placeres carnales); pero solo lo hace con la finalidad de conseguir su total sometimiento y llevarlos al territorio que administra para satisfacerse su maldad.

Otra de las oposiciones presentes en los sermones es la que se establece entre la religión andina y la religión cristiana. La religión andina se presenta como irracional, pues exige la adoración de elementos sin inteligencia (alma), las cuales no pueden escuchar los ruegos, cumplir las peticiones; pues las guacas son cosas, sin espíritu. En ellas solo habita el Diablo. Esta religión irracional se condice con el poco desarrollo mental del indio. Los ritos y objetos sagrados indígenas resultan risibles para el enunciador de los Sermones:

Pues las guacas y figuras y ydolos que teneys efcondidos y los adorays que os dire dellos?

Vnos de vofotros tienen vna piedrezita muy lifa, y de muy biua color para $\int u$ guaca, otros una ouegita hecha de plata, otros vna maçorca de mayz que lIamays Pirua, muy encubierta; otros vna figura de Ynga labrada en piedra, otros vn ydolillo vestido de cumbi de ropa chiquita, y otras mil niñerias, y bouerias con que offendeys a Dios... (Tercero Cathecismo, 1585, p. 108)

En el discurso se pone la mira en los objetos pequeños. El uso de diminutivos revela un interés del enunciador por marcar la situación inferior del indio. Frente a él se erige la elevada autoridad de Dios. De esto, podemos inferir que 
la religión cristiana requería de fieles adultos, con la suficiente racionalidad para conocer la verdadera fe y luchar por ella. La adultez no solo implica madurez intelectual, sino también física y moral.

Cuando el enunciador representa la religión andina usa un tono agresivo. Sin mediar una reflexión sobre lo que Joseff Esterman (2009) denomina pachasofía, el Sermón XVIII genera una imagen simplista, extremista y degradada de la religión del otro.

Vayanfe para burleria las guacas pongafe de lodo los Ydolos, los muchachos $\int e$ enfuzien en ellas, que todo es engaño y mentira. Y Jolo nueftro gra Dios feñor y hazedor del cielo y tierra ha de Jer adorado. y feruido y reuerenciado, y nofotros que fomos hechos a fu ymagen y Semejança, no hemos de adorar las inuenciones de los hechizeros, que para folo comer y beber fingen maldades, ni hemos de Jugetarnos a los embustes del Diablo que quiere engañarnos, y Ileuarnos a arder en el infierno mas folo a nueftro Dios todo poderofo adoramos, y bendizimos. y honramos. y reuerenciamos para fiempre jamas. Amen. (Tercero Cathecismo, 1585, p. 109)

De esta dualidad se desprende la oposición entre el sacerdote cristiano y el indígena. El primero es un medio para acceder al camino correcto; se le asocia a conceptos como belleza, juventud, solución, salvación, verdad y correcta orientación. Al sacerdote también le corresponde el concepto de castidad, que lo semeja con los ángeles, dada su "limpieza". Para el enunciador de los sermones, alejarse de la mujer marca la diferencia entre lo carnal y lo espiritual; la pureza y lo impuro: “... y la caufa porque los facerdotes y religiofos y monjas no le cafan, es por tener mas limpieza en el cuerpo, y en el anima, y afsi Jervir mejor a Dios..." (Sermón XV).

Por su parte, al sacerdote indígena se le atribuyen conceptos de fealdad, vejez, error, mentira, problema y tormento. Es un nexo entre el hombre y el Diablo. El hechicero dice las palabras del Maligno; a diferencia del sacerdote indígena (Padre), quien habla por Dios y, poseedor de este bien, tienen el don de la sanación.

Y los que no reciben efta palabra de Dios, y fé de Ie fu xpo fon defuenturados. y cōdenados a los tormentos eternos del infierno, y mucho mas

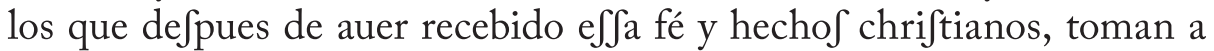

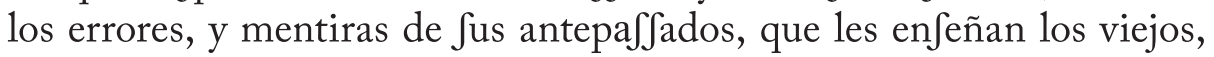
y hechizeros miniftros del Diablo, los quales os procuran apartar de la fé, y palabra de Dios, y os mandan adorar al Diablo, y no a Dios, en las guacas, y offrecer Jacrificios al Diablo, mochandole, y que en vueftras nece $\int s i d a d e s . y$ enfermedades vays a los viejos hechizeros, y digays vueftros pecados, y offrezcays vueftras cofas, lo qual todo es mētira y maldad. y ellos son unos pobres y defuenturados y tontos, y os engañan, 
porque les deys de comer, y os licuan al infierno, donde ellos arderan para Siempre jamas con el Diablo. (Tercero Cathecismo, 1585, p. 26)

Se hace hincapié en este aspecto porque se deja entender en el texto que tanto los indios como los "hechiceros" continuaban con sus prácticas paganas. En el Sermón IX se vuelve a poner el énfasis en la hechicería. El sacerdote indígena es un farsante que aprovecha los conceptos de la religión católica para beneficio propio.

Los hechizeros no os engañen, que las guacas, ni el Jol, ni el trueno no perdonan peccados, ni los rios lleuan los peccados, ni los ychuris y confe $\int$ ores libran de culpa, ni por offrecer cuyes, o coca, o cameros, o mayz, o otras cofas $\int e$ perdona el peccado que todo e $\iint o$ es mentira y engaño del Diablo, y embustes de los hechizeros que comen y beuen. (Tercero Cathecismo, 1585, p. 53)

El sacerdote indígena es "ministro del Diablo", encargado de enseñar la religión andina, fuertemente impregnada en las prácticas cotidianas como los viajes, la alimentación, funerales, construcción de viviendas, predicción del futuro, festividades, entre otros.

Otros abren las entrañas de los carneros o cuyes, o otros animales, y por ellos adevinan lo que a de fer. Todo efto enfeñan los viejos hechizeros, y

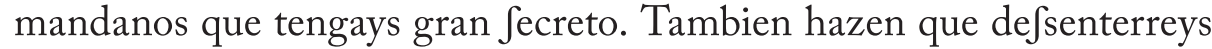
vue $\int$ tros muertos de la yglefia, y que los epulteys con huacas, y que les pongays comida y beuida. Han os enfeñado que no comenceys coja alguna $\int$ in confultar los hechizeros, y echar Juertes, y offrecer a los huacas, y afsi lo hazeys quando començays cafa, o hazeys Jementera, o vays camino, o cafays vuestros hijos. (Tercero Cathecismo, 1585, p. 112)

El sacerdote cristiano es presentado mediante la metáfora de "médico" que sana el alma. Frente a él se encuentra el "ychuri", quien literalmente es un "agente del Diablo", cuyo fin es obtener bienes terrenales y servir al Diablo, condenando a los hombres al Infierno.

Por otro lado, hallamos en los sermones la oposición goce-sufrimiento. El goce conduce a la satisfacción de la carne. La carne es la instancia en la que se afincan los deseos provenientes del mundo y del Diablo. Esto lleva finalmente a una condena segura. El placer es sensorial. Por esto, podemos decir que el cuerpo se encuentra próximo al pecado y al Diablo. En cambio, el sufrimiento es mostrado eufóricamente. Los mártires de la fe son presentados como paradigmas.

Por esta $\int a n c t a$ unction y por $\int \mathrm{u}$ piadofa mifericordia te perdone Dios todo lo que peccaste por la vifta por el oydo por el gufto y por los demas fentidos ungiendo los ojos, oydos y boca. y manos y pies, porque por 
eftas partes peccamos, quebrando la ley de Dios. (Tercero Cathecismo, 1585, p. 96-97)

Otra oposición que hallamos en el texto es el del juicio corto versus el juicio largo. La doctrina cristiana solo podía ingresar en la mente de los indígenas por el juicio corto y el lenguaje llano, pues los indios estaban más apegados a los sentidos. No se pretendía educar a los indios en cuestiones abstractas, sino en brindarles lo esencial para tener noticias de Dios.

Y afsi el eftilo de fermones, o platicas para Indios, Je requiere Jer facil y humilde, no alto ni leuatado: las claufualas no muy largas, ni de rodeo, el lenguaje no exquifito, ni terminos affectados, y mas a modo de quiē platica entre compañeros, que no de quien declama en theatros. (Tercero Cathecismo, 1585, p. 5)

De acuerdo con este texto podemos relacionar cultura occidental con lenguaje literario, ideas profundas y largas, raciocinio y religión cristiana; frente a cultura andina que se asocia con ideas cortas y superficiales y falsa religión. La religión cristiana es verdadera, propia de culturas desarrolladas; frente a las manifestaciones idolátricas primitivas, de sujetos que no dominan la escritura ni el pensamiento. Este carácter explica la presencia del Diablo en las Indias. Este jamás habría influido en personas más preparadas como los religiosos europeos.

Para los evangelizadores, los indígenas se hallaban en una etapa de oralidad pura (Zumthor, 1991), en la que el indio no habría tenido contacto con ningún sistema de escritura. El indio no podía comprender los conceptos teológicos, es decir, no podía razonar, en tanto que era un sujeto "rudo", sin el acceso a la modernidad y civilización, que son expresiones propias de Occidente, donde el conocimiento y la palabra autorizada viajan vía escrita.

Dado el poco entendimiento del indio, el Tercero Cathecismo recomendó usar ciertos discursos que puedan generar impacto en ellos, con quienes "no sirvē razones muy sutiles". Entre las estrategias discursivas adecuadas para esta tarea encontramos el símil, el ejemplo, la desmitificación, la adjetivación, las exclamaciones y apóstrofes. Para vencer al Diablo era necesario el conocimiento de métodos de impacto en el receptor. La retórica prestó estos saberes, con los cuales no solo se debía explicar la fe cristiana, sino atacar las vigentes prácticas idolátricas de los antepasados.

\section{La oposición Dios-Diablo}

Dios-padre es mostrado como una figura masculina: engendró, sin corrupción, un hijo legítimo en la Virgen María. Asimismo, es efectivamente padre de toda la Humanidad. Provee salud y alimentos; pero también es el encargado de 
aplicar sanciones. En el Sermón XVIII, Dios se presenta como un "gran fuego muy terrible" ante Moisés para entregarle sus mandamientos.

Asimismo, Dios padre administra justicia entre los hombres. En el Sermón XXIV se expresa que Jehová protege al "yndio pobrecito" contra los abusos de las autoridades (curaca, corregidor): "No ves q Dios es padre de todos, juez justo $\mathrm{y}$ recto, y que mira por los pequeños pues no se pueden defender y que castiga terriblemente a los malos".

Del mismo modo, el Padre busca una ligera homologación entre los géneros. Dios protege a la mujer: prohíbe golpearla, violarla; le exige tener un marido y una familia. Este orden busca una sociedad armoniosa basada en la dualidad varón-mujer. La lujuria, engendrada por el Diablo, genera la posesión de más de una pareja, y por ende, la destrucción de la familia.

Por e $\iint o$ no digas yo he andado con muchas mugeres y me huelgo con la que bien me parece, y no $\int$ iento mal por e $\iint o$ ni caftigo ninguno. E $\iint o$ que dize los Padres que Dios caftiga, y Je enoja con los que andan con mugeres fuera de las Juyas, deuen Jer amenazas y palabras. (Tercero Cathecismo, 1585, p. 150)

Dios domina el ámbito de la creación y el tiempo. Mientras que la palabra del hombre (verbo) solo comunicativa; la palabra divina (Verbo) es transformadora. En Retórica de la religión (2014), Kenneth Burke hace una división entre verbo y Verbo. Verbo con mayúscula corresponde a la palabra divina, correspondiente al ámbito de lo sobrenatural. El verbo, como categoría gramatical, adquiere una dimensión mayor cuando remite a acciones hechas por Dios.

El enunciador del discurso pone la mira en el carácter único de Dios (monoteísmo). Esta idea entra en contradicción con el politeísmo andino. Para el enunciador de los sermones es ofensiva la idea de que cada localidad posea su propio dios. La oposición local-universal es incompatible frente a la unidad de la Iglesia, que tenía un solo Padre.

Mientras Dios se relaciona con lo abstracto, lo racional y lo complejo; el Diablo se limita a lo concreto, lo sensorial y lo simple. El Diablo es más próximo a lo animal; y Dios, a lo espiritual. Los distintos sermones re-significan el concepto de los elementos de la naturaleza que, de poseer un carácter divino, pasan a ser cosas. Adorar las cosas resulta ahora demoniaco y condenatorio; mientras que adorar lo abstracto, lo intangible y puro lleva a la salvación.

$\mathrm{Y}$ a $\int \mathrm{i}$ vereys, que aunque $\int \mathrm{e}$ quiebre un bulto, o fe rompa una ymagen, no por e $\iint o$ los Chriftianos lloran, ni pien $\int a n$ que Dios $\int e$ les ha quebrado o perdido, porque mi Dios esta en el Cielo y nunca perece, y de la ymagen Jolo fe quiebra o pierde el palo, o el metal o el papel, de lo 
qual los Christianos no Je les da nada, ni lo tienen por $\int u$ Dios. (Tercero Cathecismo, 1585, p. 117)

De acuerdo con Rogério Haesbert (2007), el ser humano es un animal territorial. El territorio es un espacio habitado por las personas y sus códigos. El espacio se incorpora a un conjunto de discursos que "explican" la historia de sus habitantes. El indio había entablado una relación filosófica, religiosa y pragmática con su entorno. Piedras, frutos, cerros, cuevas, entre otros eran considerados guacas.

Cuando la Pacha adquirió el concepto de cosa, cuya adoración resultaba demoniaca, el indio colonizado sufrió un desequilibrio semántico. Anteriormente, la Pacha era parte de un conjunto de hierofonías, modalidades de lo sagrado en un tiempo determinado (Eliade, 1957).

Según Estermann (2009), para los andinos la sexualidad es una condición universal. A lo masculino corresponde el lado derecho, el sol, la estrella de la mañana. Asimismo, se encuentran en el ámbito de lo masculino el agua que fluye o cae, los apus, los animales y la nube. Por su parte, lo femenino implica el lado izquierdo, la luna, la estrella vespertina, la pachamama y el invierno. Se les suma la luna, las plantas y el rayo. Es decir, para los andinos, la sexualidad está presente en todo el universo; la sexualidad es cosmológica. El complemento del macho y la hembra es una condición esencial del cosmos. Según Ortiz (1993), en el mundo andino "Todo tiene sexo, cada cosa, región y hasta tiempo tienen un carácter sexual, una ubicación en el eje alto-bajo y una edad (el mundo envejece hasta morir; pero antes fue inocente, salvaje e intemperante para luego madurar y enfermar)".

En el contexto de la Evangelización, la tierra dejaba de ser divina, a la par que era ahora poseída y gobernada por otros. En este sentido, el indio era un sujeto desterritorializado. De acuerdo con el Diccionario de relaciones interculturales: diversidad y globalización (2007) la desterritorialización es definida como "la pérdida de los linderos territoriales que se han creado a partir de códigos culturales que llenan de orgullo a sus sustentadores, aunque en ocasiones resulten inaceptables para otros grupos" (66). La desterritorialización produce una "esquizofrenia cultural" caracterizada por la crisis de identidad nacional ante el despojo de lo propio. La principal consecuencia de la desterritorialización es el desarraigo de los sujetos. Estos dejan de usar los recursos y los símbolos que habían creado para administrarlos. Del mismo modo, pierden las coordenadas geográficas con las cuales organizaban su mundo. El sujeto desterritorializado es dominado por el invasor, quien ejerce una relación de poder amo-esclavo. En el espacio desterritorializado, el amo ejerce su dominio casi absoluto. El mismo sujeto pasa a ser parte de su propiedad. El cuerpo del perdedor es un territorio del amo. 
$\mathrm{El}$ territorio adquirió un concepto de rareza y ajenidad para el indio, quien debía adaptarse a la nueva sociedad y al territorio colonizado. La desterritorialización llevó a la desculturización. En el interactuar dialéctico con el entorno, el indio experimentó una re-territorialización y una aculturación a su nuevo ambiente (Santos, 2013).

Por otro lado, la figura de Dios es análoga a la del emperador. Solo puede haber uno: poderoso, severo, amoroso e incuestionable. La existencia de un solo rey, terrenal o celestial, asegura la paz y el orden. El Diablo ansia la guerra, por lo que genera la desunión, la variedad de reinos y deidades locales; es decir, uno de los objetivos del Diablo es el caos social o la anarquía.

De este modo, el indio comprende que la forma administrativa colonial es la correcta, pues forma parte de un orden semejante al celestial y bendecido por el Papa. Al sancionar y demonizar la libertad, la pluralidad e, incluso, el pensamiento racional (que desecha las falacias, paradojas y contradicciones de la mitología judeocristiana); el discurso religioso buscó el control mental. Las categorías Dios y Diablo poseen en casi todos los sermones un rol ideológico. Siendo esto así, ambos conceptos se encuentran al servicio del gobierno colonial.

Dentro de los distintos sermones, se presenta la palabra de Dios como objeto modal fundamental dentro del discurso de la evangelización. Esta palabra sagrada es heredada por Jesucristo a los profetas, quienes, a su vez, la otorgaron a los padres y demás miembros de la Iglesia. Estos tienen el rol de llevarla a todos los humanos. Solo los más santos usan esta palabra para sanar, resucitar y hacer otros milagros. La palabra de Dios otorga un saber y un poder.

Puesto que la naturaleza divina es espiritual, la casa de Dios es limpia por excelencia. Es un lugar de privación de los placeres. En la casa de Dios los cristianos sienten contrición por sus pecados. Allí se encuentra el representante de la Iglesia en un espacio privilegiado, y a los cristianos comunes del otro. Los indios se hallan de rodillas, manifestando con el cuerpo su lugar en el orden cósmico determinado por Dios y los viracochas, encargados de difundir su palabra.

Por e $\iint$ hijos mios, mirad que no perdays tanto bien, y que vegays a Miffa temprano y limpios y lauados pues venis a la cafa de Dios, y mucho mas venid con deuocion y no parleys mientras Miffa, ni mireys a mugeres. ni a las paredes, Sino hincadas ambas rodillas con mucha deuocion adorad aquella hoftia y caliz quando le alçan, daos en los pechos pidiendo perdon de vuestros peccados y por ninguna cofa dexeys de oyr Miffa el dia de fiefta, catad que os caftigara Dios en quitaros la falud, y en daros malos temporales. (Tercero Cathecismo, 1585, p. 129) 
Frente a la casa de Dios, las guacas, domicilios del Diablo, son lugares sucios, en el que un sujeto irracional que expresa ideas "que causan risa". En la casa del Diablo, los indios son engañados por hechiceros, ministros del Diablo, cuyas medicinas no curan, y cuyas palabras condenan a quien las escucha.

En el Sermón VI se adjudica al Diablo conceptos como rebelión, desafío y exilio. E1 Diablo es un sujeto desterritorializado. Por su soberbia, ha trocado su belleza en fealdad. Su nuevo territorio es el de la fealdad y dolor extremo. Este sermón relaciona diablo con supay (No obstante, debemos advertir que en el mundo andino existían supays buenos y malos. [Depaz, 2015]), huaca, pacha y otras deidades andinas que pasan a la categoría de ordinariedad, minucia, ridiculez, perdición e irracionalidad.

El hablar del Diablo es persuasivo, frente al lenguaje imperativo de Dios. Mientras Jehová da órdenes para el bien de sus hijos, el Diablo busca razones (alcanzar el placer y el saber) para generar una rebelión contra Dios. Mientras Jehová busca un hombre puro, en estado absoluto de goce; el Diablo anhela la impureza del alma para condenar a la persona, llevarlo a su territorio (el Infierno) y gozar con el sufrimiento.

El Diablo conduce al dolor físico y eterno; se instala en el cuerpo como una enfermedad incitando al pecado. Asimismo, provoca la insubordinación. Esencialmente motiva a cometer pecados, para luego informarle a Dios y este condene al infierno al pecador. El Diablo es un personaje sádico que se regocija con el dolor ajeno.

Y el diablo esta diziendo a Dios Jeñor efte mal hobre pecca cōtra ti quieres que le acabe aqui y le mate, y pague lo que merece por efte peccado. Efto dize el diablo, y tiene una grande hacha, de cortar en la mano para darte con ella. (Tercero Cathecismo, 1585, p. 155)

En el Sermón XII el Diablo se diferencia levemente de los demonios. Estos son las tropas de un ejército que se inducen al pecador a no confesarse. Asimismo, se afirma que los demonios son vomitados junto con sapos cuando se confiesan los pecados.

Guardate de callar alguno: porque vno Jolo que encubras, no vale nada tu confe $\iint$ ion: $y$ todos tus peccados $\int e$ bueluen a ti, y otro mayor, que $\int e$ llama Jacrilegio. Dios lo tiene dicho assi. Mira no te engañe el diablo. que anda por boluer a tu anima, y le pefa que le eches della. Sabe que quantos peccados dizes, tantos demonios y $\int a p o s$ feos vomitas, y $\int \mathrm{i}$ callas algunos, todos fe bueluen luego a ti. Un Christiano Je confe $\iint a u a$ una vez, y vio otro Christiano, que como Je yua confe $\int a$ ando Jus peccados, a ssi le yuan faliendo por $\int u$ boca otros tantos fapos muy Juzios: $y$ vio mas que de ay a vn rato (porque aquel chriftiano callo un peccado por verguença del Confe $\int$ or). (Tercero Cathecismo, 1585, p. 70) 
El texto confunde los conceptos andino y occidental del sapo. En la Edad Media europea, el sapo era utilizado para hacer adivinaciones, hechizos y maleficios, considerados demoniacos. En Occidente, los sapos y las ranas eran despreciados por sus venenos y por su carácter dañino, dada la percepción que de él había en la Biblia (Kieckhefer, 1992). Cristóbal de Molina apunta en Fábulas y ritos de los incas (1574) que los incas entendían el concepto de Diablo (supay) e infierno. Según el autor, en el infierno, los sentenciados comían "carbón, culebra y sapos". Para Estermann, estos animales "tienen una función de 'mensajeros' y 'mediadores". Alberdi (2008) añade que el sapo es un símbolo de la agricultura en los indios prehispánicos, pues vive en el agua, especialmente en charcos, lagunas y manantiales. Por su parte, Maximiliano Ochante (2015) explica que el sapo es símbolo de la fertilidad, pues emerge de la tierra en periodos de lluvia: "Representa la resurrección y renovación de la vida".

Al expulsar a los demonios, el religioso se convierte en un héroe del cristiano; pues vence a un enemigo que se había alojado en el cuerpo de la persona. En este caso, la lucha deja de ser abstracta y se instala en un espacio concreto: el cuerpo de la persona.

En el Sermón XIX se indica que el Diablo inventó la falsa religión de las guacas. Es el Diablo quien genera la superstición. Del mismo modo, es el él quien ha creado las festividades antiguas, con lo que la música y la danza implicadas en ellas resultan demoniacas. Los religiosos ansiaban no solo atacar los ídolos, a quienes se podían adjudicar directamente una cualidad demoniaca; sino también a toda la cultura del indio. Ansiaban generar un nuevo sujeto, absolutamente controlado y casi totalmente aculturado.

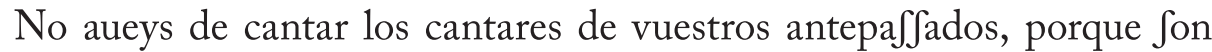
engaños del demonio. No aueys de celebrar las fiestas del Raymi, ni del ytu, ni las otras que los antiguos hazian, porque Jon fiestas en que $\int e$ adora el diablo. quando fembrays y quando cogeys vuestro mayz o papas no aueys de hazer los bayles y Taquies, ni celebrar el Aymuray, Jino dar gracias a Dios que os da la comida. (Tercero Cathecismo, 1585, p. 115)

Frente a los bailes y taquis, la Iglesia propone oraciones y cánticos que agraden a Dios. Es decir, en su afán de luchar contra el Diablo, se inhibe el movimiento y la excitación de los sentidos por medio de los ritmos antiguos. La estética divina debía desplazar a la antigua. En la oración, el movimiento del cuerpo es casi nulo. Del mismo modo, se busca sobriedad en el ornato de la vestimenta. A Dios le agrada la mesura.

En el Sermón XXIII, se genera una oposición entre la mesura y el exceso. Dios corresponde al uso equilibrado de los bienes de la Creación. El alimento, la bebida y el fuego moderado resultan racionales, civilizados y divinos. La presencia excesiva de estos se encuentran en el ámbito irracional, bestial y dia- 
bólico: "Porque os quitays lo mejor que Dios os dio que es el juyzio y razon de hombre, y de hombre os boueis cavallo y aun peor" (Tercero Cathecismo, 1585, p. 141).

La desmesura lleva al descontrol de la mente y del cuerpo, y esto conduce al pecado: hablar fuerte, pelear, maltratar físicamente al prójimo. En el Sermón XXIII, se marca con una hipérbole este aspecto: "Ay bestia mas bestia que un borracho?” (Sermón XXIII) La interrogación es dirigida al enunciatario (y al interlocutor) con el fin de orientarlo en su forma de vida.

Al alejar al hombre de la razón, se le aparta de Dios. Luz y razón son divinos, y oscuridad y sinrazón son demoniacos: "Que differencia ay de una de una cãdela a un palo defpues de apagada la luz? La Luz en el hombre es la razon y el jvizio $\int i$ le quitays el juyzio no ay differencia del hōbre a una piedra, o a un bruto" (Sermón XXIII).

Es constante la presencia la expresión "hijo del Diablo", la cual se usa para señalar a quienes cometen diversos pecados. También se usa la expresión para referir a quienes actúan al margen de la Iglesia. Veamos los distintos casos en que se aplica esta expresión:

- y los que teneys hijos por bapptizarlos, los occultays soys demonios; queréis que sean hijos del Diablo. (Sermón XXII)

- los que aporrean a sus mugeres y las maltratan, son hijos del diablo. (Sermón XXII)

- las mugeres q no sirven a sus maridos, o se andan con otros son hijas del Diablo.(Sermón XXII)

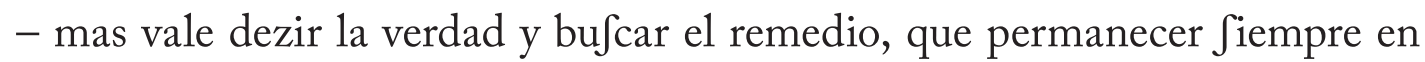
peccado, y fer hijo del diablo... (Sermón XVI)

- el que Jupiere de eftos malos hechizeros los de fcubra al padre para que no les dexe hazer mal, y el que los encubre es hijo del Diablo, y ardera por Siempre en el infierno. (Sermón XIX)

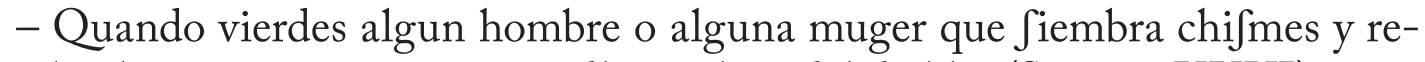
buelue a unos con otros tenedle por hijo del diablo. (Sermón XXVI)

Entre Dios, tomado como totalidad, y el Diablo encontramos las siguientes oposiciones en el nivel temático: 


\begin{tabular}{ll}
\hline \multicolumn{1}{c}{ Dios } & \multicolumn{1}{c}{ Diablo } \\
\hline Verdad & Mentira \\
Vida & Muerte \\
Eternidad & Pasado \\
Salvación & Perdición \\
Unidad & Pluralidad \\
Racionalidad & Sensualidad \\
Creación & Destrucción \\
Mesura & Exceso \\
Belleza & Fealdad \\
Luz & Oscuridad \\
Fe cristiana & Fe andina \\
\hline
\end{tabular}

En los sermones observamos una batalla contra el Diablo, la cual es de corte espiritual. La pelea "real" se dio entre Jesucristo y el Maligno en el cielo, cuando este fue derrotado y desterrado a los infiernos. Para vencer al Diablo hay que conservar y fortalecer la fe. En el Sermón XVII se brindan armas para vencer al Diablo, entre las que se encuentran expresiones de afirmación de la fe, rechazo e insultos al pecado y al Diablo. Se observa el énfasis en expresiones de carácter mágico en esta lucha: el nombre y la sangre de Cristo, así como hacer la señal de la Cruz.

O hermanos mios estad fuertes en la fe, y palabra de Dios, y refiftid a efte vuestro enemigo el diablo diziendole con mucho animo. Vete de mi maldito engañador. melltirofo, que yo foy Chriftiano baptizado. y tengo la fe de lefu Chrifto, que es mi Dios y mi Redemptor, y esta en el cielo y quiere Jaluarme. y por mi derramo Ju fangre en la cruz y alli te vencio, y me libro de tu poder. yo llamo a lefu Chifto y a el me encomiendo. mi cuerpo y mi alma. y por el efpero fer faluo y perdonado de todos mis peccados. y el me dara la falud del cuerpo que es mejor. y porna mi alma en el cielo, a el llamo yo y a el adoro. que las guacas no Jon nada, ni valen nada. (Tercero Cathecismo, 1585, p. 99)

La lucha contra el Diablo es finalmente una pelea contra la religión andina. Las armas de defensa contra el Maligno son, ya en la instancia de uso del discurso, un conjunto de ataques a la religión de los antepasados. La guaca es presentada como el territorio del Diablo en la tierra. Es el lugar en el cual el indio se desliga del tiempo presente (tiempo de la salvación) y se une al mal (tiempo pasado). La oposición presente-pasado incrementa más el grado de dependencia de los indígenas con respecto a la administración colonial. Los antepasados (independientes) obedecían al Diablo; por lo que la opción correcta es odiarlos y aceptar la colonización, relativo a un presente santificado.

En esta lucha, el hombre asume un rol activo: es el héroe de su propia historia. Si vence, conseguirá la salvación. Para derrotar al Diablo requerimos de un saber-hacer: "Dezir con el coraçon, y con la boca Iesus Iesus sea conmigo" 
(Sermón XVII). Esta modalización del lenguaje es un arma eficaz, además de otros actos que implican la ayuda de Dios: tomar el agua bendita, rezar el Padre Nuestro y el Ave María.

\section{Conclusiones}

- Las distintas oposiciones indican significados ideologizados que implican a los grupos presentes en la evangelización: religiosos e indígenas. Estos conceptos son parte estratégica del proceso de colonización de las Indias.

- Las distintas oposiciones sirvieron para instaurar un nuevo corpus ontológico en el indio. Esta nueva forma de concebir el mundo y el cuerpo propio sirvió para generar un nuevo sujeto, sometido a los nuevos dioses y sus representantes, los españoles.

- El hombre andino, que vivía en relación sinérgica con la naturaleza, fue separada de ella. La Pacha, ente animado, pasó al estatuto de cosa. En cambio, se le otorgó al indígena nuevos conceptos de dioses abstractos y angustiantemente omnipresentes.

- Para justificar la evangelización, se usó la oposición salvación-perdición. Esta requería de conceptos como alma (en oposición a cuerpo), pecado, infierno, paraíso, Dios, Iglesia, entre otros. Al apropiarse de estos conceptos, el indio ingresa en una nueva dimensión de la realidad, donde tiene un lugar inferior en la jerarquía cósmica y social.

- Oposiciones como cuerpo-alma, salvación-perdición, obediencia-desobediencia sirvieron como herramientas de control del indígena. La demonización del cuerpo y la salvación del mismo mediante la palabra de Dios son de real importancia en el proceso de la Colonización.

- La oposición Dios-Diablo es la más importante en los sermones del Tercer Concilio Limense. Ambos remiten a santidad y salvación frente a pecado y perdición. Lo eufórico y divino abarca conceptos como obediencia, abstinencia, limpieza, belleza, unicidad, mesura, verdad, racionalidad. Por su parte, lo disfórico implica ideas como desacato, placer, muerte, fealdad, soledad, dolor, perdición, multiplicidad, exceso, sinrazón, mentira, ficción.

- Al relacionar lo demoniaco con la cultura andina, los evangelizadores no buscaron comprender la civilización incaica. Al demonizarla, su objetivo fue extinguirla. La colonización requería de la muerte del "runa" (hombre andino) para instaurar el cristiano pecador. 
- El concepto de Diablo que se enseñó en el Tercer Concilio Limense fue asociado con referentes de la cultura andina. Los distintos elementos de la antigua religión fueron demonizados. De igual forma, se demonizaron los bailes, las canciones y los distintos rituales que se denominaron idolátricos, a partir de la llegada de los españoles.

\section{Notas}

$1 \mathrm{El}$ artículo se basa en uno de los capítulos de la Tesis doctoral Representaciones del diablo en las crónicas Verdadera relación de la conquista del Perú y provincia del Cuzco llamada nueva castilla de Francisco de Xerez, Instrucción al licenciado Lope García de Castro de Titu Cusi Yupanqui y en los sermones del Tercer Concilio Limense.

\section{Referencias}

Alberdi, A. (2008). Las constelaciones de la vía láctea en la visión de los quechuas y los usos del espacio-tiempo sur andino. En Ruma-Yachachiy, 1- 35. http:// www.alberdi.de/Vialacque060208.pdf

Amat, H. (2016). Ideología y Religión de los Incas. Lima: Fondo Editorial de la UNMSM.

Barañano A., García J., Cátedra M. \& Devillard, Eds. (2007). Diccionario de relaciones interculturales: diversidad y globalización. Madrid: Editorial Complutense.

Benavente, T. (2014). Historia de los indios de la Nueva España. Madrid: RAE.

Burke, K. (2014). Retórica de la religión. México D.F., FCE.

Concilio provincial de Lima (1583). Doctrina christiana y Catecismo para instrvccion de los Indios, y de las mas personas que han de ser enseñadas nuestra Sancta fé. Con un confessionario, y otras cosas necessarias para los que doctrinan, que se contienen en la página siguiente. Lima: Imprenta de Antonio Ricardo.

Courtés, J. (1997). Análisis semiótico del discurso. Edit. Gredos.

Depaz, Z. (2015). La cosmo-visión andina en el Manuscrito de Huarochirí. Lima: Perfecto Vicio.

Eliade, M. (1994). Lo sagrado y o profano. Colombia: Editorial Labor.

Estermann, J. (2009). Filosofía andina. Sabiduría indigena para un mundo nuevo. La Paz: ISEAT

Fontanille, J. (2001). Semiótica del discurso. Lima: Fondo Editorial de la Universidad de Lima.

-.(2012). Semiótica y literatura. Ensayos de método. Fondo Editorial de la Universidad de Lima.

Fromm, E. (1956). Psicoanálisis y religión. Buenos Aires: Psique. 
-. (2012). El miedo a la libertad. Barcelona: Paidos Studio.

Gruzinski, S. (2016 [1990]). La guerra de las imágenes: De Cristóbal Colón a "Blade Runner" (1492- 2019). Ciudad de México: FCE.

Haesbaert, R. (2007). Território e multiterritorialidade: um debate. Universidad Federal fluminense. En GEOgraphía. Año IX, Nº 37. Recuperado de http:// www.geographia.uff.br/index.php/geographia/article/viewFile/213/205. Consulta 23/04/2018

Kieckhefer, R. (1992). La magia en la Edad Media. Barcelona: Crítica.

Lafaye, J. (1981). Los conquistadores. México D.F.: Siglo XXI

Medinaceli, X., Coord. (2001). El discurso de la evangelización del siglo XVI. La Paz: Instituto de Estudios Bolivianos $N^{\circ}$ 9. UMSA.

Methol, A. (1968). La conquista espiritual. Montevideo: ARCA.

Molina, A. (1565). Confesionario mayor en lengua mexicana y castellana. México: Imprenta de Antonio de Espinosa.

Montoya,J. (2011). ¿ Conquistar indios o evangelizar almas? Politicas de sometimiento en las provincias de las tierras bajas del Pacifico (1560-1680). N . XIX.

Montoya Guzmán, J. D. (2011). ¿Conquistar indios o evangelizar almas?: políticas de sometimiento en las provincias de las tierras bajas del Pacífico (1560-1680). En Historia Crítica, (45),pp.10-30. Retrieved April 09,2019, from http://www.scielo.org.co/scielo.php?script=sci_arttext\&pid=S0121-16172011000300002\&l$\mathrm{ng}=\mathrm{en} \& \mathrm{tln} \mathrm{g}=$.

Ortiz, A. (1993). La pareja y el mito. Estudios sobre las concepciones de la persona y de la pareja en los Andes. Lima: Fondo Editorial de la PUCP.

Pane. R. (1987). Apuntes de Relación acerca de las antigüedades de los indios. México D.F. Siglo XXI.

Parret, H. (2008). Epifanias de la presencia. Ensayos semio-estéticos. Fondo Editorial de la Universidad de Lima.

Ochante, M. (2015). Simbolismo de sapos y culebras en la cosmovisión andina [Blog]. Ciberandes magazín. Recuperado de http://www.ciberandes-magazin. $\mathrm{com} /$ category/arte-y-cultura/

Santos, M. (2013). O espaço da ciudadania e outras reflexōes. Porto Alegre: fundaçao Ullyses Guimarães.

Valenzuela , E. (2015). Kerigma: preguntas teóricas en torno a la primera evangelización de América (Antillas, 1510-Nueva España, 1524). En Historia Crítica, (58), 13- 32.

Zavala, S. (1947). La filosofía politica en la Conqusta de América. México D.F.: FCE.

Zumthor, P. (1991). Introducción a la poesia oral. Madrid: Taurus 